\title{
The Effects of Design Strength, Fly Ash Content and Curing Method on Compressive Strength of High Volume Fly Ash Concrete: A Design of Experimental
}

\author{
Mochamad Solikin ${ }^{1, *}$, and Budi Setiawan ${ }^{1}$ \\ ${ }^{1}$ Civil Engineering Department, 57102, Universitas Muhammadiyah Surakarta, Jl. A. Yani \\ Tromol Pos 1 Pabelan Surakarta, Jawa tengah, Indonesia
}

\begin{abstract}
High volume fly ash concrete becomes one of alternatives to produce green concrete as it uses waste material and significantly reduces the utilization of Portland cement in concrete production. Although using less cement, its compressive strength is comparable to ordinary Portland cement (hereafter OPC) and the its durability increases significantly. This paper reports investigation on the effect of design strength, fly ash content and curing method on compressive strength of High Volume Fly Ash Concrete. The experiment and data analysis were prepared using minitab, a statistic software for design of experimental. The specimens were concrete cylinder with diameter of $15 \mathrm{~cm}$ and height of $30 \mathrm{~cm}$, tested for its compressive strength at 56 days. The result of the research demonstrates that high volume fly ash concrete can produce comparable compressive strength which meets the strength of OPC design strength especially for high strength concrete. In addition, the best mix proportion to achieve the design strength is the combination of high strength concrete and $50 \%$ content of fly ash. Moreover, the use of spraying method for curing method of concrete on site is still recommended as it would not significantly reduce the compressive strength result.
\end{abstract}

\section{Introduction}

Concrete, composed of cement, aggregate, water and optional admixture, is the main material for construction and its consumption becomes a second large material of human use after water $[1,2]$. Almost all of construction elements need concrete not only for their structural elements such as slab, beam, column and foundation but also for non-structural element such as concrete wall and roof tile. Moreover,

\footnotetext{
*Corresponding author: msolikin@ums.ac.id
} 
concrete is used for all types of construction such as building, road pavement, and bridge. Therefore, the provision of concrete needs a large amount of material.

The demand of large material to produce concrete raise many ideas of alternative materials as part of replacement of concrete ingredient. This replacement is not only to reduce the cost of production but also to save the environment. The reduction of cost production is due to the fact that the alternative material is usually taken from waste material. Moreover, the use of waste material results in the reduction of energy as there is no need to produce new material, which means that the replacement concrete is environment-friendly material.

One of the most preferable material as cementitious or part of cement replacement is fly ash, a by-product of combustion in coal fire power plant [3, 4]. In 2010 , the annual production of coal is 780 million metric tonnes, which further produces 117 million metric tonnes of fly ash or $3.3 \%$ of global cement consumption for concrete [5-7] [3-5]. One of ideas to use significant amount of fly ash as cementitious in concrete production is termed as high volume fly ash concrete in which the maximum amount of cement used is $50 \%$ as the other binder utilized class $\mathrm{C}$ or class $\mathrm{F}$ fly ash [8] [6]. The technology has proven to give much advantage to hardened concrete properties and has comparable strength to OPC concrete [9-11].

To get comparable strength to OPC (Ordinary Portland Cement), previous researcher such as Shaikh, Supit and Parker applied high volume fly ash concrete for high design strength concrete in which the total amount of binder is quite higher than its application on normal strength concrete [12-14]. For example: at 56 days testing age, $42 \mathrm{MPa}$ compressive strength of High Volume Fly Ash Concrete is similar to 42 compressive strength of OPC concrete in which the cement content is twice of that of HVFA concrete. In addition, the more fly ash is used in High volume fly ash concrete, the lower the compressive strength becomes [15]. Moreover, the curing regime becomes a factor which gives effect to the compressive strength result of high volume fly ash concrete based on comparison of water immersing and steam curing method [16]. However, daily spraying becomes the most available curing method for high volume fly ash concrete which is cast on site.

Having discussed related literature, it can be noted that the design strength, the amount of cement replacement and the curing method becomes influential factors which can give effects to compressive strength of high volume fly ash concrete. Hence, this paper presents an investigation report of the effect of those factors to the compressive strength of concrete by conducting a series of specimen test. The design of Experimental (DOE) is the method which is used to prepare and analysed the specimens by utilizing Minitab 17, a design of experimental software.

\section{Research method}

This research employed experimental program to analyse the effects of design strength, fly ash content and curing method on compressive strength of high volume fly ash concrete. The factors to be analysed are shown in Table 1, in which high and low value refer to different methods of application. The table shows that the design experiment for each factor consists of two values, low value and high value. The design strength comprises $25 \mathrm{MPa}$ and $45 \mathrm{MPa}$ design strength; the fly ash content 
consists of $50 \%$ and $70 \%$ and the curing method consists of fully immersion and spraying method. Fly ash content of $70 \%$ means that the concrete binder is composed of $30 \%$ cement and of $70 \%$ fly ash. Moreover, in spraying curing method, the concrete specimen was regularly sprayed twice a day for the period of 14 days.

Table 1. Composition of each factor.

\begin{tabular}{|l|l|l|l|}
\hline No & Factor & Low value & High value \\
\hline 1 & Design strength & $25 \mathrm{MPa}$ & $45 \mathrm{MPa}$ \\
\hline 2 & Fly ash content & $50 \%$ & $70 \%$ \\
\hline 3 & Curing method & Fully immersion & Spraying \\
\hline
\end{tabular}

The composition of each factor examined were inputted into Minitab 17, a statistical software to conduct design of experimental. The result of mix proportion combination for full factorial design is shown in the following picture:

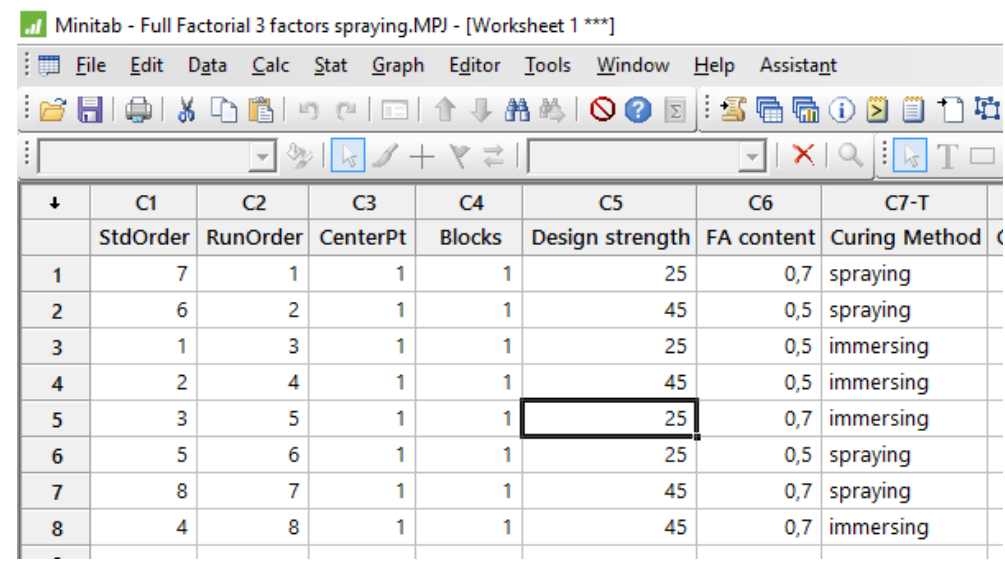

Fig. 1. Design of experiment combination.

Based on mix proportion combination result from Minitab 17, a series of concrete cylinder specimens were prepared with the diameter of $15 \mathrm{~cm}$ and the height of $30 \mathrm{~cm}$. The total number of specimens were 24 concrete cylinders. Besides, the composition of mix proportion for the cylinder was prepared based on ACI mix proportion for normal strength and for high strength. For high volume fly ash concrete, fly ash is utilized as part of cement replacement and the mix proportion is shown in the flowing table.

Deploying ACI design of normal strength concrete of $25 \mathrm{MPa}$, the mix proportion used $376 \mathrm{~kg}$ binder to produce $1 \mathrm{~m}^{3}$ of concrete. Therefore, HFVA (High volume fly ash) used $188 \mathrm{~kg}$ cement and $188 \mathrm{~kg}$ fly ash, whereas UHFVA (Ultra High volume fly ash) used $113 \mathrm{~kg}$ of cement and $264 \mathrm{~kg}$ of fly ash. The mix proportion of fine aggregate and coarse aggregate remained the same for both HFVA and UHFVA. Since High volume fly ash concrete used low water content of $0.35,0.4 \%$ of sika viscocrete 1003 to the total binder was used. Similar to the mix proportion of normal design strength, high strength concrete used $537 \mathrm{~kg}$ of total binder which was proportionally distributed to Portland cement and fly ash. 
Table 2. Mix proportion of concrete.

\begin{tabular}{|c|c|c|c|c|c|c|}
\hline Mix Design & $\begin{array}{c}\text { Cement } \\
\left(\mathrm{kg} / \mathrm{m}^{3}\right)\end{array}$ & $\begin{array}{c}\text { Fly ash } \\
\left(\mathrm{kg} / \mathrm{m}^{3}\right)\end{array}$ & $\begin{array}{c}\text { Fine } \\
\text { Aggregate } \\
\left(\mathrm{kg} / \mathrm{m}^{3}\right)\end{array}$ & $\begin{array}{c}\text { Coarse } \\
\text { Aggregate } \\
\left(\mathrm{kg} / \mathrm{m}^{3}\right)\end{array}$ & $\begin{array}{c}\text { Water } \\
\left(\mathrm{kg} / \mathrm{m}^{3}\right)\end{array}$ & $\mathrm{SP}$ \\
\hline $\begin{array}{c}\text { Normal strength } \\
\text { HFA }\end{array}$ & 188.0 & 188.0 & 637.0 & $1,250.0$ & 128 & $0,4 \%$ \\
\hline $\begin{array}{c}\text { Normal strength } \\
\text { UHVFA }\end{array}$ & 113.0 & 264.0 & 637.0 & $1,250.0$ & 128 & $0,4 \%$ \\
\hline $\begin{array}{c}\text { High strength } \\
\text { HVFA }\end{array}$ & 269.0 & 269.0 & 613.0 & 919.0 & 188 & $0,4 \%$ \\
\hline $\begin{array}{c}\text { High strength } \\
\text { UHVFA }\end{array}$ & 173.0 & 173.0 & 613.0 & 919.0 & 188 & $0,4 \%$ \\
\hline
\end{tabular}

Before casting the specimen, the materials for concrete were tested to ensure that all materials satisfied the quality of standard material for concrete. The tests for fine aggregate were clay lumps and water absorption tests. In addition, the coarse aggregate was tested for its abrasion resistance. Visual test for cement and chemical content of fly ash was also conducted.

After all materials were tested, they were mixed in a drum rotating mini mixer to achieve the design slump before it was casted into cylinder mould. On the following day, the specimens were removed from the mould and curing method were applied based on curing method regime. At the age of 56 days, the specimens were tested for its compressive strength.

\section{Results and discussion}

\subsection{Materials tested}

The clay lump test and water absorption test for fine aggregate show the result value of $2.86 \%$ and $1.63 \%$, both of which satisfy the standard of fine aggregate for concrete, whereas the abrasion test for coarse aggregate results in the value of $21.54 \%$, which is below the maximum degradation of coarse aggregate of $40 \%$.

The fly ash which is used in this experiment was produced by PLTU Tanjung Jati Jepara, Central Java and the chemical content analysis was conducted at Laboratorium Pengujian dan Kalibrasi BARISTAND, Surabaya, East Java. As shown in Table 3, the fly ash used in this research is class F Fly ash as the total amount of $\mathrm{SiO}_{3}+\mathrm{Al}_{2} \mathrm{O}_{3}+\mathrm{Fe}_{2} \mathrm{O}_{3}$ is $86.36 \%$ [17].

Table 3. Chemical properties of fly ash (mass \%).

\begin{tabular}{|c|c|c|}
\hline Chemical analysis & $\begin{array}{l}\text { Fly ash PLTU } \\
\text { Tanjung jati }\end{array}$ & $\begin{array}{l}\text { ASTM Standard } \\
\text { for class F }\end{array}$ \\
\hline Silika dioxida, $\mathrm{SiO}_{2}$ & 66.50 & \multirow{3}{*}{$\begin{array}{c}\mathrm{SiO}_{2}+\mathrm{Al}_{2} \mathrm{O}_{3}+ \\
\mathrm{Fe}_{2} \mathrm{O}_{3} \text { min. } 70 \%\end{array}$} \\
\hline Aluminium oxida, $\mathrm{Al}_{2} \mathrm{O}_{3}$ & 16.20 & \\
\hline Fery oxida, $\mathrm{Fe}_{2} \mathrm{O}_{3}$ & 3.66 & \\
\hline $\mathrm{TiO}_{2}$ & 0.10 & \\
\hline Magnesium oxida, $\mathrm{MgO}$ & 21.20 & \\
\hline $\mathrm{CaO}$ & 16.40 & \\
\hline
\end{tabular}




\subsection{Analysing factor}

After testing the compressive strength of all concrete cylinder specimens at their age of 56 days, the data were analysed using MINITAB 17. The analysis results i.e. the main effect factor, the significant factor and the size of effect are shown in the following graphs:

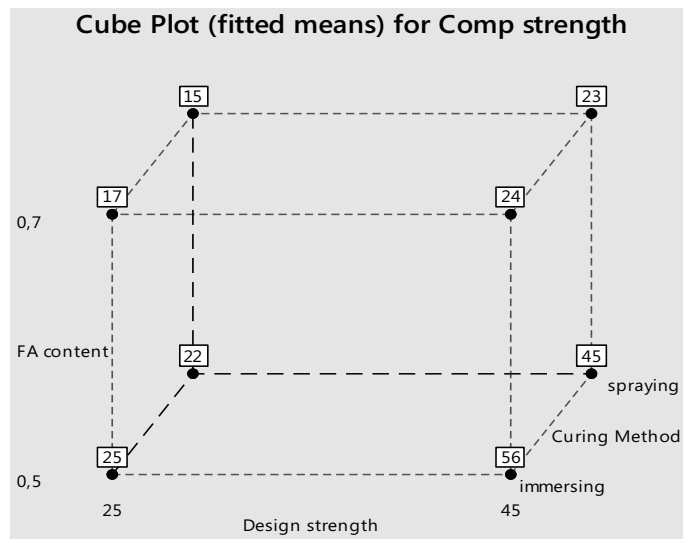

Fig. 2. Cube plot of compressive strength for each mix proportion.

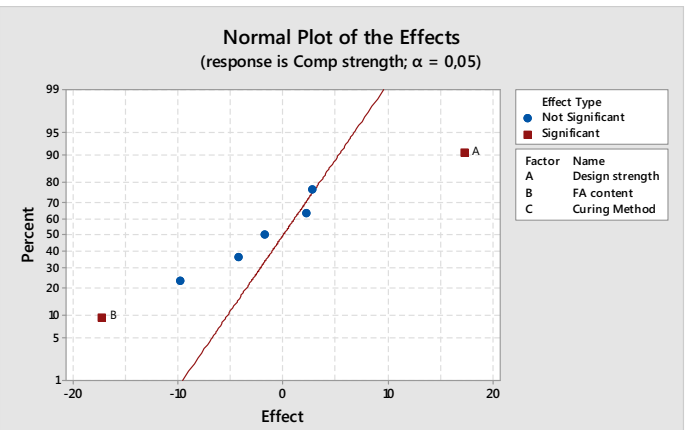

Fig. 3. Significant factor.

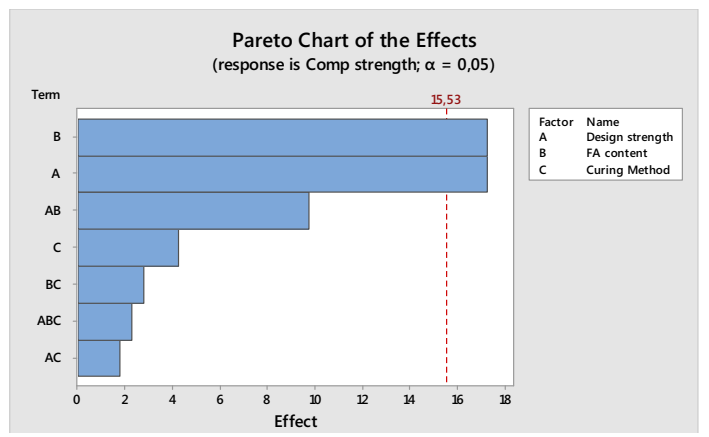

Fig. 4. Size of effect. 


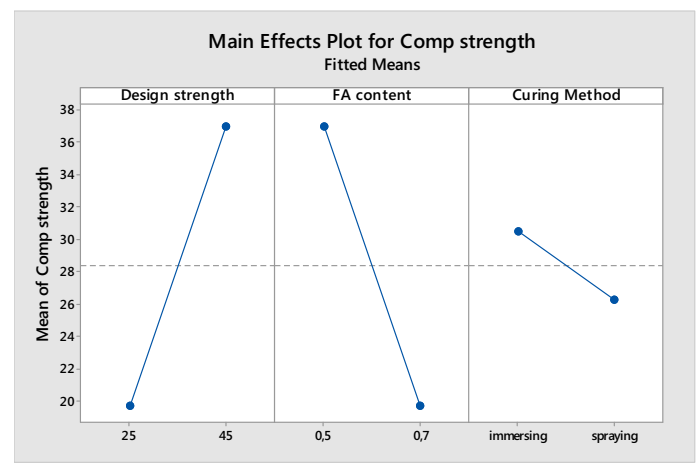

Fig. 5. Average of main plot for compressive strength.

As seen in the above graphs, the factors that give significant effect to the compressive strength of concrete are design strength and fly ash content. The effect can be obtained on the condition that the design strength of the concrete is $f^{\prime}{ }_{c}=45$ $\mathrm{MPa}$ and the fly ash content as cement replacement is $50 \%$. On the contrary, the normal strength design of $f^{\prime}{ }_{c}=25 \mathrm{MPa}$ and the high content of fly ash as cement replacement of $70 \%$ are not recommended to be used for the mix proportion, as it is would lead to lower compressive strength.

The higher cement content in high design strength concrete significantly leads to more $\mathrm{Ca}(\mathrm{OH})_{2}$ content, a product of cement hydration, which then reacts with silica, a main chemical content in fly ash, and beneficially results in better hydration process in High Strength concrete. Nevertheless, lower cement content in combination with high level fly ash content in high strength concrete leads to the lower compressive strength of concrete, a condition which confirms the previous research [15].

Those graphs also reveal that curing method of fully immersing and spraying do not significantly give effect on compressive strength result of high volume fly ash concrete. Nevertheless, as the possible curing method on site is spraying water on the concrete, spraying is still adequate as curing method for concrete.

Further, when design strength and fly ash content factors are used together in the mix design of concrete, they would give more significant effect rather than what the curing method role to get higher or lower compressive strength.

\section{Conclusion}

The result of the research demonstrates that high volume fly ash concrete can produce comparable compressive strength as design strength especially for high strength concrete. In addition, the best mix proportion to achieve the design strength is the combination of high strength concrete and 50\% content of fly ash as replacement. Moreover, the use of spraying method for curing method of concrete on site is still recommended, as it would not significantly reduce the compressive strength result.

Further research must be conducted on why high strength design of concrete mix proportion makes the compressive strength of High volume fly ash better rather 
than normal strength design. Besides, the effect of curing method on the compressive strength of larger dimension concrete needs to be clarified.

This research is made possible because of the Hibah Bersaing grant from Directorate Research and Community Service (Ditlitabmas) Ministry of Research and Higher Education Indonesia under the contract number of 186.15/A3-III/LPPM/V/2016. The authors wish to acknowledge the support given by technical staff in PT Pioner Beton Surakarta and concrete laboratory at Universitas Muhammadiyah Surakarta as well as the assistance of Qanitah Masykuroh in proofreading.

\section{References}

[1] V. Atakan, J. Jain, D. Ravikumar, L. McCandlish and N. DeCristofaro, Technologies that Reduce Water Use in Cement and Concrete Help Global Industry Address Mounting Concerns of Water Scarcity, (2016), Retrieved on October 12, 2016 from http://solidiatech.com/wp-content/uploads/2016/08/ Addressing-Water-Scarcity-in-Cement-Concrete-Industries-Solidia Technol ogies-August-2016.pdf

[2] L. J. Murdock, J. D. Dewar and K. M. Brook, Concrete materials and practice, Edward Arnold, London, UK, (1991)

[3] S. H. Kosmatka, B. Kerkhoff, and W. C. Panares, Design and Control of Concrete Mixtures 14th edition, Portland Cement Association, Illinois, USA, (2003)

[4] E. G. Nawy, Fundamentals of High Strength High Performance Concrete, Longman Group Limited, London, UK, (1996)

[5] E. Safitri and Djumari, Kajian Teknis dan Ekonomis Pemanfaatan Limbah Batu Bara (Fly Ash) pada Produksi Paving Block, J. of Media Teknik Sipil, 9(1), 36-40 (2009)

[6] C. Heidrich, H. J. Feuerborn and A. Weir, Coal Combustion Product: A Global Perspective, Proc. of 2013 World of Coal Ash (WOCA) Conference, Lexington, KY, United States, (2013)

[7] Mineral resources program, Cement, 2015, Retrieved on August 20, 2016 from https://minerals.usgs.gov/minerals/pubs/commodity/cement/mcs-2015cemen.pdf

[8] V. M. Malhotra and P. K. Mehta, High Performance, High-Volume Fly Ash Concrete: materials, mixture proportioning, properties, construction practice, and case histories. 2nd ed., Supplementary Cementing Materials for Sustainable Development Inc., Ottawa, Canada, (2005)

[9] A. Bilodeau and V. M. Malhotra, High-Volume Fly Ash System: Concrete Solution for Sustainable Development, ACI Materials J., 97(1), 41-50 (2000)

[10] M. Solikin, S. Setunge, and I. Patnaikuni, The Influence of Lime Water as Mixing Water on The Compressive Strength Development of High Volume Ultra Fine Fly Ash Mortar, Proc. of The Sixth International Structural Engineering and Construction Conference (ISEC-6), Zurich, Switzerland, (2011)

[11] M. Solikin, S. Setunge, and I. Patnaikuni, Experimental Design Analysis of Ultra Fine Fly Ash, Lime Water, and Basalt Fibre in Mix Proportion of High Volume Fly Ash Concrete, Pertanika J. Science \& Technology, 21(2), 589600 (2013) 
[12] F. U. A. Shaikh, S. W. M. Supit, and P. K. Sarker, A study on the effect of nano silica on compressive strength of high volume fly ash mortars and concretes, J. Materials \& Design, 60(1), 433-442, (2014)

[13] F. U. A. Shaikh and S. W. M. Supit, Compressive strength and durability properties of high volume fly ash (HVFA) concretes containing ultrafine fly ash (UFFA), J. of Construction and Building Materials, 82(8), 192-205, (2015)

[14] T. F. Prihantoro and M. Solikin, Perkembangan Kuat Tekan Beton Mutu Tinggi dengan Memanfaatkan Teknologi High Volume Fly Ash Concrete, Proc. of Simposium Nasional Rekayasa Aplikasi Perancangan Industri (RAPI XVI), Surakarta, Indonesia, (2015)

[15] C.-H. Huang, S.-K. Lin, C.-S. Chang, and H.-J. Chen, Mix proportions and mechanical properties of concrete containing very high-volume of Class $\mathrm{F}$ fly ash, J. of Construction and Building Materials, 46(9), 71-78, (2013)

[16] H. Yazici, S. Aydin, H. Yigiter, and B. Baradan, Effect of steam curing on class $\mathrm{C}$ high-volume fly ash concrete mixtures, Cement and Concrete Research, 35(6), 1122-1127, (2005)

[17] ASTM C 618-03, Standard specification for fly ash and raw calcined natural pozzolan for use as mineral admixture in portland cement concrete, Annual Book of ASTM Standard, Philadelphia, United States, (2003) 